UDK: 336.71(517.3)

DOI: $10.2478 /$ jcbtp-2021-0017

Journal of Central Banking Theory and Practice, 2021, 2, pp. 133-155

Received: 18 November 2019; accepted: 28 April 2020

Enkhzaya Demid *

\section{Heterogeneity in the Relationship Between NPLs and Real Economy: Evidence from the Mongolian Banking System}

\begin{abstract}
The paper analyses the relationship between the banks' credit risk and macroeconomic conditions by addressing the following questions; (i) How are macroeconomic shocks transmitted to lending risk depending on the ban-specific features? (ii) Are the effects of macroeconomic shocks different across the loan portfolios in various economic sectors? Unlike the common assumption in the literature, the empirical analysis considers banks' heterogeneity and diversification across borrowers. It employs heterogeneous panel SVARs and standard SVAR models on a dataset from 2002. Q1 to 2019.Q1. The results suggest that the deterioration in credit quality is affected by both macroeconomic and bank-specific factors, with substantial heterogeneity in the magnitudes and timing in terms of the type of loans in various business sectors and bank characteristics. In particular, we find strong evidence of cyclical sensitivity of loan quality, and about $1 / 4$ of banks' NPLs increases stronger in response to the shocks to growth, exchange rate, interest rate, and profitability. The highly profitable banks tend to less engage in excessive risk-taking, resulting in lower NPLs, whereas the relation of asset size to NPLs is not significant for the sample. A growth shock plays a prominent role in explaining the variation of NPLs for the trade and mining sectors. Similarly, the loan supply shock is the main determinant for the construction sector's NPLs, while the exchange rate shock is the most responsible for the manufacturing sector. The interest rate shock and exchange rate shock are the most effective factors on NPLs of consumer loans. Finally, the feedback effect of NPLs shows that deterioration of credit quality slows down economic growth.
\end{abstract}

*Bank of Mongolia

Email:

enkh8zaya@gmail.com 
Keywords: NPLs, macroeconomic determinants, bank heterogeneity

JEL Classification: G21, E32, E44

\section{Introduction}

Banking institution plays a crucial role in the financial system and the economy. There are many experiences of the financial crisis associated with deteriorating asset quality in the banking system, especially rapidly building-up of nonperforming loans (NPLs) in both developed and developing countries (see, e.g., Demirgüç-Kunt and Detragiache, 1998; González-Hermosillo, 1999). These experiences imply that macroeconomic and financial shocks, as well as credit market distortions, have highly related to each other, which brings considerable costs to the real economy. The reasons behind this, financial stability is involved with the factors that spread the macroeconomic vulnerability to the financial system.

In general, banking sector performance is affected by factors related to the macroeconomic conditions (systematic factors) or internal drivers such as bank lending policies, risk management quality, and staff morale (non-systematic factors), as well as business activities (firm-level). On the macroeconomic side, common findings of theoretical and empirical studies show that the state of the business cycle is the inevitable factors that directly affect bank's asset quality through balance sheets and creditworthiness of various economic agents. In more detail, credit requirements are loosened in the period of economic booms and tightened the cycle turns, which amplifies the impact of an economic downturn on credit risk (see, e.g., Rajan, 1994; Ruckes, 2004). Besides, aiming to earn more profit from loans, banks can be motivated to lend more to lower-quality borrowers over their potential, which lead to loan defaults when the economy faces recession. More importantly, bank lending is in turn, crucial for a well-functioning economy. An increase in NPLs deteriorates bank's liquidity and profitability, causing to limit the bank's credit supply. Ultimately, a credit crunch could lead to subsequent business failures that raise the NPL ratio further up. It would generate an inefficient resource allocation through investment and demand, thereby harm the country's long-run growth prospects.

In Mongolia, like other developing countries, a source of financing business heavily relies on bank lending, and the majority of bank asset consists of loans; thus, the highest risk in the banking system is also sourced from loans. Consequently, the credit quality and the macroeconomic situation will mutually affect each other, and the negative shock to each of them will reinforce the effects, may have longer-lasting effects. Therefore, exploring the determinants of non-per- 
forming loans is an issue of great importance for ensuring both macroeconomic and financial system sustainability. Moreover, from the perspective of policymakers and regulators, understanding these links, monitoring how resilience credit quality to the deterioration in economic conditions, and assessing whether shocks would have a systemic impact is essential to elaborate financial regulations and to improve the feedback mechanisms of anti-crisis.

The main objective of this paper is to analyse the link between macroeconomic developments and credit risk in the case of the Mongolian banking system. This paper employs the heterogeneous panel SVAR methodology developed by Pedroni (2013) using 14 commercial banks' variables and macroeconomic data on quarterly basis from 2004 to 2018. Furthermore, we examine separate analyses for the respective loan portfolio in different economic sectors using standard a SVAR.

We believe that our findings make several contributions to the existing literature. The literature often assumes that the effects of macroeconomic shocks on credit quality are homogenous for all banks, but economic shocks can affect heterogeneously across banks in reality. For instance, if a given bank's loan portfolio mostly concentrated in sectors less dependent on the economic cycle or has a well-diversified loan portfolio, it may not much suffer from the impact of macroeconomic shocks. On the other hand, results could be different depending on the bank's credit policies and risk-taking behaviour. To address this issue, the model allows us to capture the dynamic interactions between bank-specific and macroeconomic developments taking into account the cross-sectional dynamic heterogeneities. Moreover, the model permits to cover a broad set of macro and bank-level information to model linkages between individual banks and different macroeconomic variables. Apart from contributing to the literature, the paper may also have important practical implications for commercial bankers and bank supervisors in the Mongolian banking system.

The remainder of this paper is organized as follows: Section 2 summarizes related literature and outlines the theoretical arguments on factors affecting nonperforming loans. Section 3 analyses some stylized facts in Mongolia. Section 4 describes the research methodology and data. Section 5 discusses the empirical results and finally concludes in Section 6.

\section{Literature review}

Several arguments explain the determinants of credit quality. The theoretical models generally explain the interaction between macroeconomic and financial 
system by involving financial conditions in the different phases of the business cycle. According to Bernanke, Gertler and Gilchrist (1998), credit markets, as a financial accelerator, are often procyclical, and economic shocks affect credit quality through asymmetric information between borrowers and lenders, as well as balance sheet effects. The empirical studies under this topic can be categorized in terms of macroeconomic, banking, institutional, and firm-level information, which may affect the credit quality. Here is an overview of key outcomes:

In a group of studies investigated the effects of macroeconomic development on credit quality is explained by the relationship between the business cycle and borrower's ability to pay back the loan. The period of economic expansion boost income and strengthen the financial capacity of households and business, decreasing loan burden in the repayment, which is reflected in the higher quality of the bank's loan portfolio. However, during an economic expansion, banks tend to operate a liberal lending policy by lowering credit standards and increasing their credit supply (Keeton, 1999; Fernandez De Lis, Martinez Pagés and Saurina, 2000). At the time, the banks are highly likely to increase lending to borrowers who have low credit quality; thus, the creditworthiness of borrowers deteriorates in the phase of the economic downturn, thereby loan default materialize. In addition, the literature provides evidence that macroeconomic indicators such as interest rates, inflation, asset prices, unemployment are significant determinants of non-performing loans.

Another group of the literature emphasizes that bank lending policies and management factors influence credit quality. There are several empirical studies suggesting that bank-specific factors such as the size of the bank's assets, cost efficiency, capital adequacy, profitability, credit terms, and ownership structure of commercial banks can affect its credit quality. These factors generally describe the bank's risk-taking activities, moral hazard, and managerial behaviours (see, e.g., Berger and DeYoung, 1997; Podpiera and Weill, 2008; Louzis, Vouldis and Metaxas, 2010).

In addition to macroeconomic and bank-specific aspects, regulatory and institutional factors are essential for credit risk. The studies examining these factors argue that the country's business and legal environment, institutional quality, and political stability play an essential role in the quality of the bank's credit. For example, lack of credit information-sharing institutions and credit rating agencies, weak coordination of enforcement and contractual obligations, unsound foreclosure, and bankruptcy resolution may affect the level of non-performing loans. (see, e.g., Dash and Kabra, 2010; Jappelli and Pagano, 2002; Godlewski, 2004). 
Some empirical results based on firm-level information show that macroeconomic factors have a different impact on their loan risk depending on the firm sales growth, profitability, funding costs, debt-to-income ratio, asset growth, size, and age (see, e.g., Benito and Young, 2001; Bunn and Redwood, 2003). The other problem in practice is that the irresponsible borrower who has a less financial sophistication often over expect the future income inconsistent with the economic pattern can cause financial problems to redeem its debts.

In this study, the first two categories, macroeconomic and bank-level factors, are considered.

\section{Stylized facts of NPLs in Mongolian Banking System}

The stylized facts indicate the evident dependence between macroeconomic factors and credit quality in different phases of the business cycle in Mongolia. The period considered in this section goes from 2008 till 2018.

As depicted in Figure 1, there are negative co-movements between the level of NPLs and macroeconomic variables (GDP growth and loan growth), reflecting that the loan quality in our banking system is closely linked with the economic cycle. Looking at the credit quality in terms of currency, $17.1 \%$ of all foreign currency-denominated loans were classified as non-performing loans, compared to 9.5\% of those in MNT in the first quarter of 2019. Figure 2 shows that positive comovement between the level of NPLs and exchange rate depreciation over time.

Figure 1: Economic growth, loan growth and NPLs

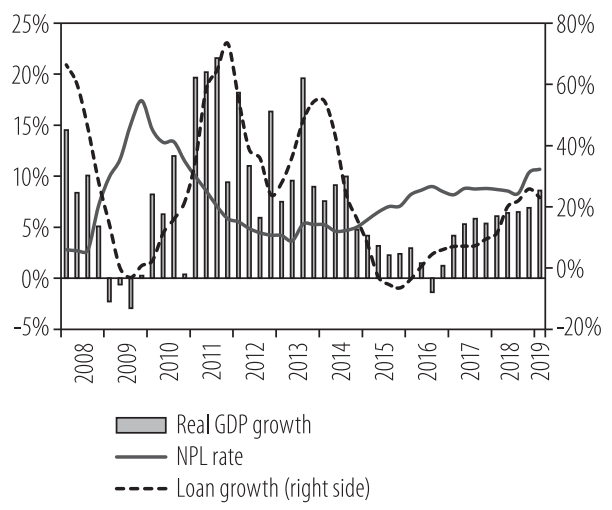

Figure 2: Exchange rate and NPLs in foreign currency

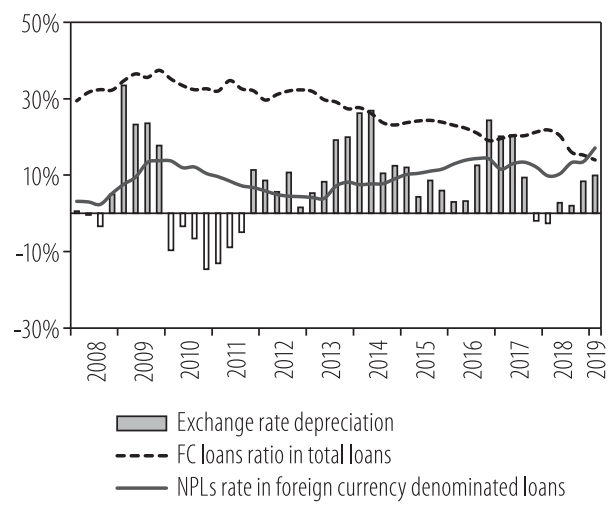


The global economic crisis exerted a negative impact on the Mongolian economy, and banks have experienced a significant increase in NPLs. Following the crisis, some banks have failed, and the Mongolian government was incurring considerable costs to recover the banking sector. The most negative situation was in the last quarter of 2009, where the economic recession made difficulty in borrower's ability to meet their financial obligations to banks, resulting in the level of NPLs reached $17.4 \%$. Notably, the borrowers who took loans denominated in foreign currency have significantly faced the credit risk due to the sharp depreciation of the exchange rate.

In the aftermath of the crisis, rapid credit growth and supportive economic environment led to improve the health of the financial system; thus, NPLs were relatively stable in the range of $4.0-5.0 \%$ between 2012 and 2014. However, since 2014, these trends were reversed due to a slowdown in the real economy and unfavourable external circumstances. Commercial banks tended to adopt a cautious lending stance, and credit growth slowed significantly in 2013-2014, pushing the NPL ratio to increase sharply. In 2015-2016, the non-performing loans in commercial banks raised again in the worsened economic conditions caused by fluctuation in commodity price, exchange rate depreciation in short time, shrinking capital inflow in Mongolia. Even though the economy has been recovering (reached 5.1\%) from the beginning of 2017, the credit quality is still not improved. In recent years, credit quality had been at concerning levels and reached $10.7 \%$ in the first quarter of 2019 .

Looking at banks' loan portfolios, we can see that lending to individuals and private sector are at a similar level (almost 50\%), but credit quality issued to the

\section{Figure 3: Nonperforming loans}

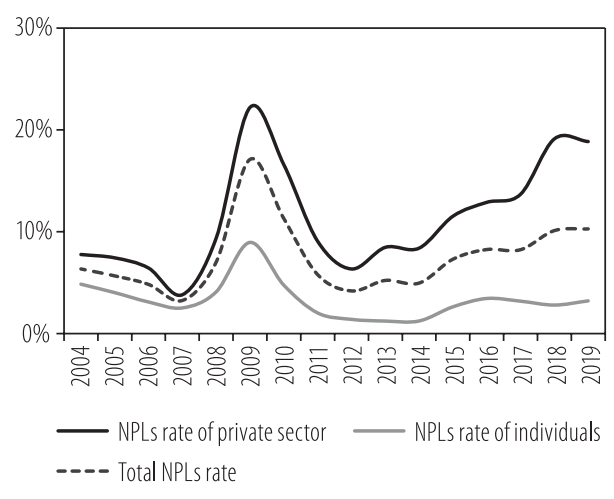

Figure 4: NPLs and Past due in arrears loans, by economic sector, 2019q1




private sector is more likely to reflect the impact of macroeconomic shocks. For example, in the first quarter of 2019, the level of NPLs of individual's loans were $3.1 \%$, while the private sector's NPLs were $18.8 \%$ (Figure 3 ).

For the overall structure of lending growth in the banking system, loans granted to trade, manufacturing, and mining sectors were dominant in 2000-2004; however, since 2004, the volume of the construction sector and consumer loans has been increasing. Also, mortgage and real estate sector's loans have been proliferating as a result of the "Housing mortgage financing program" implemented by the Mongolian government in 2013. This high level of loan concentration in the banking sector is associated with our less diversified economic structure, transmitting the adverse effect of the real sector to the credit risk of the banking sector.

In fact, most of the loan portfolios in the banking sector (60\%-70\%) consist of the trade, manufacturing, real estate, construction, and mining sectors in 20082018. Meanwhile, $74.6 \%$ of NPLs in the banking system comprise these sectors (Figure 4). For instance, in the first quarter in 2019, non-performing loans in the mining sector were $36.2 \%$, those in the manufacturing sector were $25 \%$, and for the construction sector NPLs stood at $16.4 \%$, including loan principal in arrears that were $21.6 \%$. The construction industry has been significantly affected by the economic downturn of recent years and it has been experiencing liquidity issues, which affects its loan repayment capacity.

\section{Data and Model specification}

\subsection{Data and hypothesis}

We decompose the banking data into common and idiosyncratic components. In the model, macroeconomic factors are considered as common shocks that affect NPLs of individual banks. This systemic factor's block consists of the variables: (i) output gap; (ii) inflation; and (iii) nominal exchange rate. Moreover, banklevel features that can explain differences in banks' responses to macroeconomic shocks are included in the model as idiosyncratic shocks. This bank-specific block consists of the variables: (i) bank-level interest rate; (ii) risk-taking variables include the bank asset size (SIZE) and profitability (ROA); (iii) nonperforming loans (NPLs) for individual banks.

In the model, we use an unbalanced panel dataset that consists of 14 commercial banks and macroeconomic data covering the period from 2002.Q1 to 2019. Q1. Moreover, time series aggregate data over the period used for the secondary 
analysis. The macroeconomic variables are collected from the Statistical Bulletin of the Bank of Mongolia and the National Statistical Office (NSO). The bank-level data were obtained from the Quarterly Reports of Commercial Banks. The variables are based on theoretical hypotheses that are expected to be consistent with empirical results.

\section{Macroeconomic variables:}

Phases of the business cycle (GAP): As a financial situation and income of borrowers tend to move with business cycles, individuals' and firms' income decreases and unemployment rises during an economic contraction. Therefore, borrowers face difficulty in repaying their debt obligations, which leads to increase in credit risk. Conversely, in an economic expansion, borrower's capacity to service their debt would improve. The output gap is one of the variables to represent the business cycle. It is expressed as the difference between actual GDP and potential GDP, which is calculated using the HP filter.

Inflation (LCPI): The effect of inflation on loan quality could be ambiguous. On the one hand, higher inflation may make debt servicing easier by reducing the real value of outstanding debt. On the other hand, inflation decreases the real income of borrowers when price and wages are sticky so that NPLs are likely to increase (Klein, 2013). In addition, when inflation increases, the interest rate would increase by tightening monetary policy, which increases the cost of borrowers. In the model, inflation is expressed as a log of consumer prices index.

Exchange rate (LE): Like inflation, exchange rate depreciation may have a negative or a positive effect on NPLs. For instance, in a country with a flexible exchange rate regime and a higher level of loan dollarization, exchange rate depreciation may have a rising effect on NPLs. Moreover, currency depreciation can improve debt servicing capacities of export-oriented firms and lower NPLs, while it can adversely affect the capabilities of loan repayment by the borrowers with foreign-denominated loans or importers, thus raising NPLs ratio. Exchange Rate is expressed as a log of the nominal exchange rate (MNT/USD).

\section{Bank-specific variables:}

Interest rate ( $R$ ): As interest rate indicates the debt service cost of borrowers, the higher interest rate has more pressure of repaying debt. We assume banks charging a higher interest rate is associated with higher NPLs. 
Profitability (ROA): Bank profitability may reflect the risk appetite of banking managers. Generally, higher profitable banks are less likely to be encouraged to invest in risky projects so that asset quality is relatively good. Conversely, inefficient banks are likely to lend more to riskier borrowers in order to increase their profit in the period of economic expansion (Klein, 2013). This risk action can be seen in indicators such as return on asset, which is calculated as the ratio of net income to total assets for individual banks.

Bank size (SIZE): Larger banks may have better management and relatively reliable borrowers, as well as well-diversified loan portfolios, hence the quality of loan portfolios is likely to be good (Rajan, and Dhal, 2003). However, empirical studies have not reached a common conclusion. Bank size can be measured by the share of each bank asset in the total banking system assets.

NPLs: Non-Performing Loans to total loans ratio (NPL) is used as a proxy for loan quality, which is measured as the ratio of non-performing loans to total loans in the percentage of a given bank.

We apply the Fisher-ADF panel unit root tests to determine the stationarity of the variables for unbalanced panel data. The augmented Dickey-Fuller (ADF) test is also applied for time series data. The results indicate that all the variables are stationary in levels, except for CPI, exchange rate, GDP in the mining sector. The bank-specific and other sector-specific variables are expressed as ratios, showing stationary. The series are seasonally adjusted using the X13-ARIMA procedure. The description of all variables is provided in the Appendix.

\subsection{Overview of the model specification}

The empirical strategy consists of two parts.

In the part I, we analyse whether the impact of macroeconomic and bank-specific shocks differs across individual banks. It uses the heterogeneous panel SVAR methodology to estimate the response of NPLs of individual banks to the two sets of structural shocks. In this model, macro variables are used to identify the common shocks that affect individual banks, and bank-level data relates to bankspecific idiosyncratic shocks. The model allows us to capture the cross-sectional dynamic heterogeneities, capturing bank-level features that can explain differences in lending responses to these shocks.

In the panel SVAR model, the vector of demeaned variables used in our model expressed as $z_{\mathrm{it}}=\left(g a p_{t}, l c p i_{t}, r_{i t}, l_{t}, b_{i t}, n p l_{i t}\right)^{\prime}$, which are subscripted by the bank 
index $i$ and the quarterly index t. Here, $g a p_{t}$ is output gap, $l c p i_{t}$ is the logarithm of consumer price index, $r_{i t}$ represents nominal interest rate, $l e_{t}$ is the logarithm of the nominal exchange rate (MNT/USD), $b_{i t}$ indicates the bank's risk-taking behavior, and $n p l_{i t}$ denotes non-performing loans of each bank. Our structural vector moving average representation can be expressed $\Delta z_{i t}=A_{i}(L) \epsilon_{i t}$, where $\mathrm{A}_{\mathrm{i}}(\mathrm{L})=\sum_{j=0}^{\mathrm{Q}} A_{j} L^{j}$ the moving average coefficients that give us the structural impulse responses. The orthogonal structural shocks are decomposed into idiosyncratic, $\overline{\epsilon_{t}}$, and common shocks, $\widehat{\epsilon_{l t}}, \epsilon_{i t}=\Lambda_{i} \overline{\epsilon_{t}}+\widehat{\epsilon_{l t}}$, with diagonal covariance matrices $\Omega_{\bar{\epsilon}}=I$. The shocks are mutually orthogonal, where $\Lambda_{i}$ is a diagonal matrix of the member specific loadings. The individual members of the panel respond to both their idiosyncratic shocks and to shocks that are common across members of the panel.

By taking the matrix of the short-run responses, $A_{i}(0)$ to be lower triangular, we can identify the structural shocks by imposing restrictions. Thus, we impose contemporaneous restrictions between variables based on priority assumption for the Mongolian economy, which is followed by the recursive structure of the short-run response matrix $\mathrm{A}_{i}(0)$. In this model, the shocks are identified in the following order. $\epsilon_{\mathrm{it}}=\left(\epsilon_{t}^{r e a l}, \epsilon_{t}^{\text {inf }}, \epsilon_{i t}^{r}, \epsilon_{t}^{e}, \epsilon_{t}^{\text {bank }}, \epsilon_{t}^{r i s k}\right)^{\prime}$. Consistent with the theoretical hypothesis, we assume that unexpected inflation shocks have a contemporary impact on the domestic interest rate, the nominal exchange rate, and financial sector variables, but not on real shock. Real GDP and the overall price level react with a delay to interest rate shock. Nominal exchange rate shocks do not alter contemporaneously real GDP, inflation, and interest rates. Unanticipated banking shocks do not affect macroeconomic variables within the same period. We allow the credit quality in the banking sector to respond to all shocks.

In part II, considering banks' loan portfolio concentrates on a few economic sectors relating to an economic structure of Mongolia, we assess how the effects of macroeconomic shocks on credit quality vary for the borrowers in different economic sectors. In more detail, we examine the credit risk by splitting our sample into four groups according to its economic sector classification; (i) wholesale and retail trade sector, (ii) construction sector, (iii) mining sector, (iv) manufacturing sector, as well as (v) consumer loans.

For this section, the model is estimated using a structural VARs approach for the individual sector's information. In the model, MVA representation is expressed as $z_{t}=A(L) \varepsilon_{t}$, where $A(L)$ is a polynomial matrix in $\mathrm{L}, z_{t}$ is a vector of macroeconomic variables, $\varepsilon_{t}$ - structural innovations vector. In more detail, we use the following variables set for each sector: $z_{t}=\left(\operatorname{lrgd} p_{i t}\right.$, loan_ratio ${ }_{i t}, n p l_{i t}, l c p i_{t}$, $\left.r_{t}, l e_{t}\right)$ where, $\operatorname{lrg} d p_{t}$ denotes real GDP contributed from individual sectors, $l c p i_{t}$ is logarithm of consumer price index, $r_{t}$ is short term interest rate, $l e_{t}-\operatorname{loga}$ - 
rithm of nominal exchange rate, loan_ratio ${ }_{t}$ represents the share of individual sector's loans in the total loans, $n p l_{t}$-nonperforming loans of individual sector. In addition, $l x p i$ - export price index is included as an exogenous variable. The model can also be identified by imposing short-run restrictions on the elements of matrix $\mathrm{A}(0)$. The structural shocks are identical to previous assumptions, $\varepsilon_{t}=\left(\varepsilon_{\text {treal }} \rightarrow \varepsilon_{\text {tloan }} \rightarrow \varepsilon_{\text {tinf }} \rightarrow \varepsilon_{\text {tr }} \rightarrow \varepsilon_{\text {te }} \rightarrow \varepsilon_{\text {bank }}\right)$.

\section{Estimation results and discussion}

\subsection{Results for panel estimation}

To visualize the transmission of the common macroeconomic shocks to the individual bank credit risk, we present impulse response functions of the NPLs to shocks to the output gap, inflation, and exchange rate in Figure 5. Here the black line illustrates the median, and the green (upper) line illustrates the $75^{\text {th }}$ percentile, and the blue (bottom) line shows the $25^{\text {th }}$ percentile of IRFs. The optimum lag in the estimation is selected for two quarters. Figure 5 reveals substantial heterogeneity after all macroeconomic shocks, in line with theoretical assumptions.

Figure 5: Selected impulse response functions of NPLs to macroeconomics shocks

The level of nonperforming loans is negatively affected by the business cycle, tend to decline in response to the economic expansion shock. The median impulse response shows that 1-unit standard deviation positive shock to the output gap reduces the nonperforming loan rate by 0.5 basis points after 3 quarters at most. There are significant differences in the magnitude of the impulse response for the NPLs across banks, which may involve the economic sector concentration in loan portfolio. In fact, most of the bank lending is directed to business sectors which are mainly depending on business cycles in Mongolia. For example, over the past ten years, nearly half of the lending has been directed to mining, manufacturing, and construction. Therefore, when these economic sectors are in financial difficulties, whole banking sectors could face systematic risks. In line with previous empirical studies, this result supports the view that credit quality tends to be procyclical.

Inflation shock does not have an unambiguous significant effect on the credit quality, which is consistent with the theoretical assumption. For instance, at the $25^{\text {th }}$ percentile of banks' reaction function has the potential to reduce nonperforming loans. One explanation is that higher inflation erodes the real value of outstanding debt, as well as economic expansions, allows the business to make more profit; thus, making debt servicing easier. However, inflation may reduce real incomes, making difficulty to repay their loans. The $75^{\text {th }}$ percent quantile shows that there is likely a subset of loan performances for which inflation shocks result in increasing NPLs.

It is shown that the level of NPLs increases after depreciating nominal exchange rate shock, with a significant degree of heterogeneity in terms of magnitudes. According to the median response function, NPLs rise immediately after the exchange rate shock and observed the highest effect after four quarters. For the median responses indicate that one standard deviation increase in the nominal exchange rate would reduce the NBL ratio by 0.3 basis points. The response of NPLs of banks with a large number of loan portfolios in foreign currency tends to be stronger to exchange rate shock. In contrast, the response at the $25^{\text {th }}$ percentile shows that credit risk can be relatively low for banks with the lower amount of foreign currency lending or dominant loans to export-oriented firms.

Figure 6 illustrates the impulse response functions of non-performing loans to the bank-specific shocks. The variation in the response of non-performing loans reflects the effects of idiosyncratic shocks of the individual bank. 
Figure 6: Selected impulse response functions of NPLs to bank specific shocks
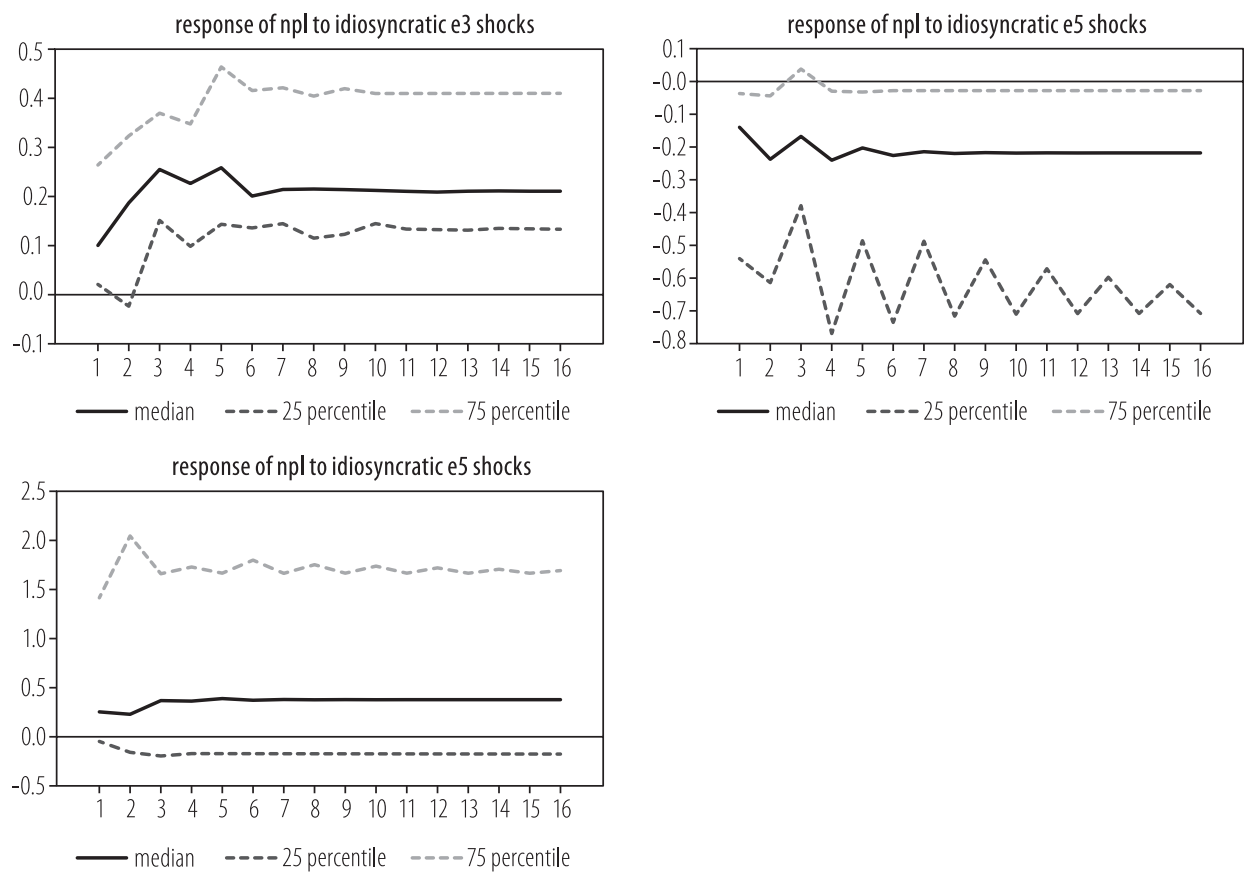

Concerning the bank's risk-taking Figure 7: Response of gap: shock to NPLs behaviour, the two variables, namely profitability and asset size, are considered. These can be used to test the moral hazard hypothesis. Credit risk declines following a profitability shock, which may reflect that banks with higher profit may not be encouraged to involve in riskier business in order to increase their profit so that credit quality is relatively good. In contrast, lower profitable banks tend to invest

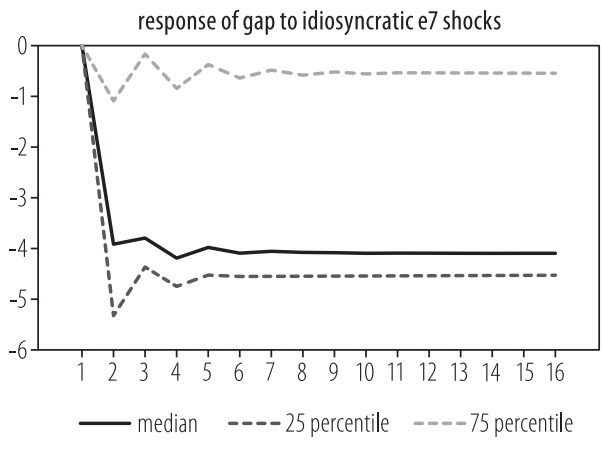
in riskier business sectors, resulting in higher future NPLs. According to our estimates, an increase of ROA by one-unit standard deviation leads to 0.40 basis point increase in the NPLs ratio for the median response. 
We expect that small banks are more exposed to higher NPLs than large banks because of lower net worth and lack of diversification. However, contrary to expectations, our result shows that asset size does have a significant effect on the level of NPLs.

We also find that credit quality deteriorates following the increasing interest rate shock as it indicates the pressure of debt repayment by borrowers. The result shows that commercial banks that charge higher interest rates tend to experience greater non-performing loans. The biggest impact for median response is the 0.3 basis point rise in non-performing loans ratio to the one standard deviation of interest rate with a 3 -quarter lag.

Finally, we analyse a feedback effect from NPLs to the real economy (Figure 7). The shock to increase the level of non-performing loans leads to decline in the real output gap after the two quarters later. This is because a higher level of nonperforming loans increases the operating costs of banks and lead to tightening the lending conditions. As a result, it could reduce credit supply and thereby slow down economic growth. Likewise, entrepreneurs who are struggling to repay their loans may be avoiding investment in new projecta, which may harm economic activity.

\subsection{Are the effects of macroeconomic shocks uniform across the NPLs categories in different economic sectors?}

We continue our analysis by presenting the results of the models estimated separately for the different sub-categories of NPLs: (i) wholesale and retail trade; (ii) construction; (iii) mining; and (iv) manufacturing; as well as (v) consumer loans. We report the estimated impulse response functions and variance decompositions of the shocks in the Appendix. Optimal lag selection tests are also reported in the Appendix.

Credit risk in the trade sector: The results show that an increasing growth shock to the wholesale and retail trade sector improves the quality of loans in this sector over 2-5quarters, with the most impact being observed in the 3rd quarter after the shock. The exchange rate depreciation shock is associated with rising NPLs of the given sector after 3 quarters. In the case of inflation shock, the loan quality of the trade sector deteriorates over 5-8 quarters. The vast majority of the variations in non-performing loans of the sector is explained by the growth shock in the trade sector (20-25\%) at medium horizons. 
Credit risk in the construction sector: Credit quality in the construction sector deteriorates in response to exchange rate depreciation shock, while improved following the growth shocks to this sector. The construction sector's growth declines the non-performing loans for the 3-6 quarters, with the most impact after 4 quarters. The price shock has a negative impact on the loan quality in this sector after 2-4 quarters. However, the non-performing loans raise following the increasing loan supply shock in the construction sector and the exchange rate depreciation shock for 2-5 quarters. Overall, the shock to the lending growth in this sector plays the most significant role in the credit risk of the construction sector.

Credit risk in the manufacturing sector: The quality of loans issued to the manufacturing sector is positively affected by the shocks to economic growth (after 3 quarters) and inflation (after 2 quarters). Exchange rate shock deteriorates the loan quality for 6 quarters and tends to be relatively persistent. The exchange rate shock accounts for the greatest share (14-20\%) of the variation in NPLs of this sector in the medium run.

Credit risk in the mining sector: The growth shock to the mining sector has a negative impact on the non-performing loans of this sector for 2-5 quarters, with the most impact in the third quarter. In addition, inflation shock slowdowns the NPLs after 4 quarters, but the exchange rate shock has no significant effect on the NPLs of the mining sector. The effects of the shocks to loan growth and interest rates show statistically insignificant results. The growth shock to the mining sector explains $17-30 \%$ of the variation in the non-performing loans ratio of this sector.

Credit risk in the consumer loan: The consumer NPLs declines in response to a shock to increasing ratio of consumer lending to total loans. The interest rate shock (after 2-5 quarters) and the exchange rate depreciation shock (after 2 quarters) negatively affect the quality of consumer loans. The economic expansion shock improves the quality of loans for the 1-3 quarters. The interest rate shock accounts for about $6 \%-30 \%$ of the variation in the NPLs ratio of the consumer lending, and the economic growth and the exchange rate shock, each contribute about $10 \%$, respectively.

\section{Conclusion and Policy Implications}

This paper investigated the determinants of credit risk in the Mongolian banking system. The empirical evidence reveals that macroeconomic shocks have different effects on loan quality, depending on the type of loans in various economic sec- 
tors and bank characteristics. Overall, the effects of the macroeconomic shocks on the loan quality are in line with theoretical perspectives, confirming that business cycles, exchange rate, and interest rate are the most important factors affecting the loan performance having the highest effect after 3-4 quarters. But the magnitude and timing of these effects are heterogeneous across banks. About 1/4 of all banks' NPLs increases stronger in response to the shocks to growth, exchange rate, interest rate, and profitability while they have a relatively small impact on $25 \%$ of banks' lending. The variation in the response of non-performing loans indicates the asymmetric impact of common shocks on individual banks and banking idiosyncratic shocks.

In fact, most of the lending is directed to business sectors which largely depend on business cycles in Mongolia. For example, over the last 10 years, nearly half of the lending is directed to the mining, manufacturing, and construction industries. If these economic sectors are in financial difficulties, whole banking sectors could face systematic risks. Thus, banks should take into account the real economic performance when extending loans given the loan portfolio. According to business sectors, MNT depreciation has adverse effects on loan performance of the construction, manufacturing, and trading sectors, as well as consumer loans. Considering that more than $20 \%$ of the issued loans in the Mongolian banking system have been in foreign currency over the past 10 years, the banks should consider preventing negative effects of the exchange rate depreciation. The response of NPLs to inflation shocks, however, differ not only in terms of magnitude but also of the sign. The empirical result suggests that the higher inflation the economy has, the lower level of non-performing loans of trade and manufacturing sector the banks experience.

We find that less (highly) profitable banks are less incentivized to invest in riskier business sectors, resulting in higher (lower) NPLs. Thus, banks with low profitability must assure their managers to avoid excessive risk-taking. And the last, the relation of the asset to NPL is not significant for the sample, but banks with big assets must make a diversification policy for their asset portfolios. NPLs increase following rapid credit growth, as it is often associated with looser lending standards, resulting in higher NPLs.

Further, the results suggest that the determinants of NPLs vary across the economic sectors. A growth shock plays a prominent role in explaining the variation of NPLs for the trade and mining sectors. Similarly, the loan supply shock is the primary determinant for the construction sector's NPLs, while the exchange rate shock is the most responsible for the manufacturing sector. The interest rate shock and exchange rate shock are the most effective factors on NPLs of consum- 
er loans. The greater the common factors in the dynamics of credit risk across different economic sectors, more likely the economy is to be exposed to these shocks.

Finally, the feedback effect of NPLs to the economy emphasizes that deterioration of loan quality slows down economic growth, and this, in turn, could further increase NPLs. Thus, macroeconomic instability has imposed the risks on financial sectors and vice versa. Therefore, implementing an appropriate macroeconomic policy to manage the ups and down of business cycles and monitor vulnerability of banks to macroeconomic shocks is of crucial importance in reducing credit risk and enhancing financial and macroeconomic stability. 


\section{References}

1. Ahlem Selma Messai, Fathi Jouini (2013). Micro and Macro Determinants of Non-performing Loans, International Journal of Economics and Financial Issues. Vol. 3, No. 4, 2013, pp.852-860

2. Bayar, Y. (2019). Macroeconomic, Institutional and Bank-Specific Determinants of Non-Performing Loans in Emerging Market Economies: A Dynamic Panel Regression Analysis. Journal of Central Banking Theory and Practice, 2019, 3, pp. 95-110

3. Benito, A. and Young, G.. (2001). Hard Times or Great Expectations?: Dividend omissions and dividend cuts by UK firms. Bank of England working papers147, Bank of England.

4. Berger, A. N. and DeYoung, R. (1997). Problem loans and cost efficiency in commercial banks. Journal of Banking and Finance. 21(6), 849-870

5. Bernanke, B., Gertler, M. \& Gilchrist, S. (1998). The financial accelerator in a quantitative business cycle framework. NBER WP 6455.

6. Bunn, P. and Redwood, V. (2003). Company accounts based modeling of business failures and the implications for financial stability. Bank of England, WP No 210.

7. Dash, M. and Kabra, G. (2010). The determinants of non-performing assets in Indian commercial bank: An econometric study. Middle Eastern Finance and Economics. Vol 7. 94-106.

8. Demirgüç-Kunt, A., and Detragiache, E. (1998). The Determinants of Banking Crises in Developing and Developed Countries. IMF, Vol 45. No.1.

9. Fernandez de Lis, S., Martinez Pagés, J., and Saurina, J.. (2000). Credit Growth, Problem Loans and Credit Risk Provisioning in Spain. Working Paper No. 0018, Banco de Espana.

10. González-Hermosillo, B. (1999). Determinants of ex-ante banking system distress: A macromicro empirical exploration of some recent episodes, IMF Working Paper, 33.

11. Godlewski, C.J. (2004). Bank capital and credit risk taking in emerging market economies. Journal of Banking Regulation. Vol. 6, No. 2.

12. Jappelli, T. and Pagano, M. (2002). Information sharing, lending and defaults: Cross-country evidence. Journal of Banking and Finance. Vol. 26, issue 10, 2017-2045

13. Keeton, W.R. (1999). Does Faster Loan Growth Lead to Higher Loan Losses? Federal Reserve Bank of Kansas City, Economic Review. 84(2), 57-75.

14. Klein, N. (2013) Bad Loans in CESEE: Determinants and Macroeconomic Performance. IMF Working Paper, WP/13/72, Washington D.C.:

International Monetary Fund. 
15. Louzis, D.P., Vouldis, A.T., Metaxas, V.L. (2010). Macroeconomic and bankspecific determinants of non-performing loans in Greece: a comparative study of mortgage, business and consumer loan portfolios. Bank of Greece

16. Pedroni, P. (2013). Structural Panel VARs. Econometrics. 1(2), 180-206

17. Podpiera, J. and Weill, L. (2008). Bad Luck or Bad Management? Emerging Banking Market Experience. Journal of Financial Stability. 4, pp. 135-148.

18. Rajan, R. and Dhal, S.C (2003). Non-performing loans and terms of credit of public sector banks in India: An empirical assessment. Reserve Bank of India Occasional Paper. 24(3), 81-121.

19. Rajan, R. (1994). Why bank credit policies fluctuate: A theory and some evidence. Quarterly Journal of Economics. Vol. 109, pp. 399-441.

20. Ruckes, M. (2004). "Bank competition and credit standards", Review of Financial Studies. Vol. 17, pp. 1073-1102.

21. TOPBAŞ Turguttopbas, N. (2018). Are Capital Ratios Procyclical? Evidence from Turkish Banking Data. Journal of Central Banking Theory and Practice, 2018, 3, pp. 159-180 


\section{Appendix}

Figure 8: IRF for the wholesale and retail trade sector
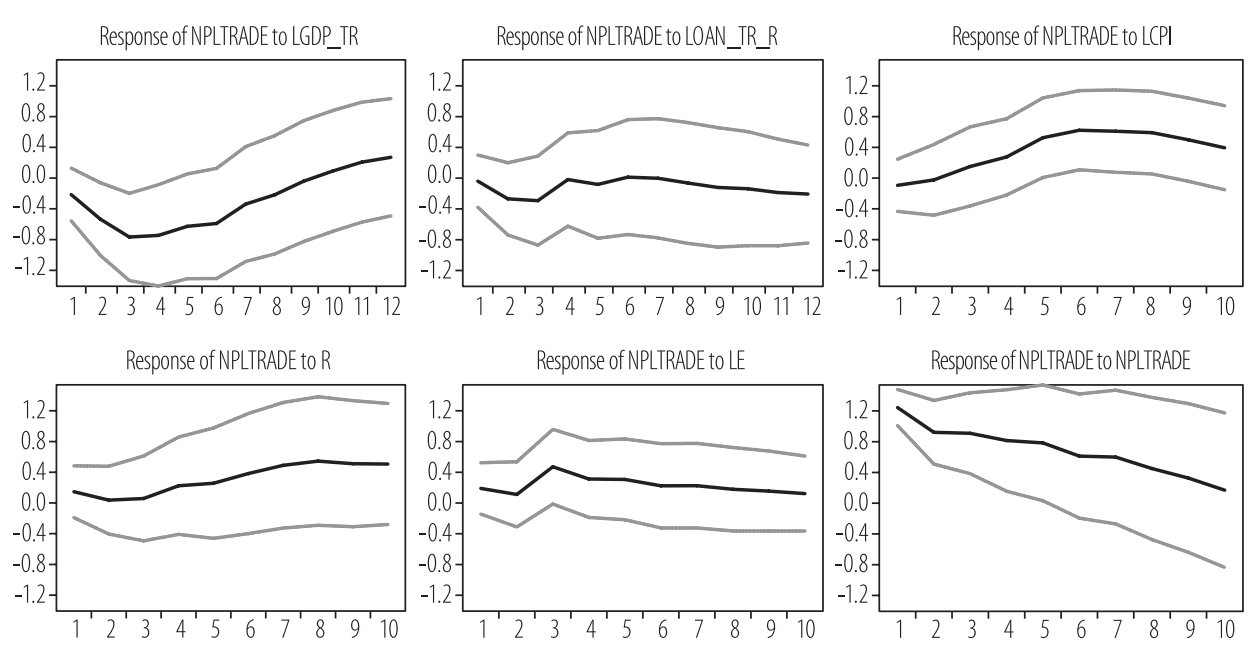

Figure 9: IRF for the construction sector
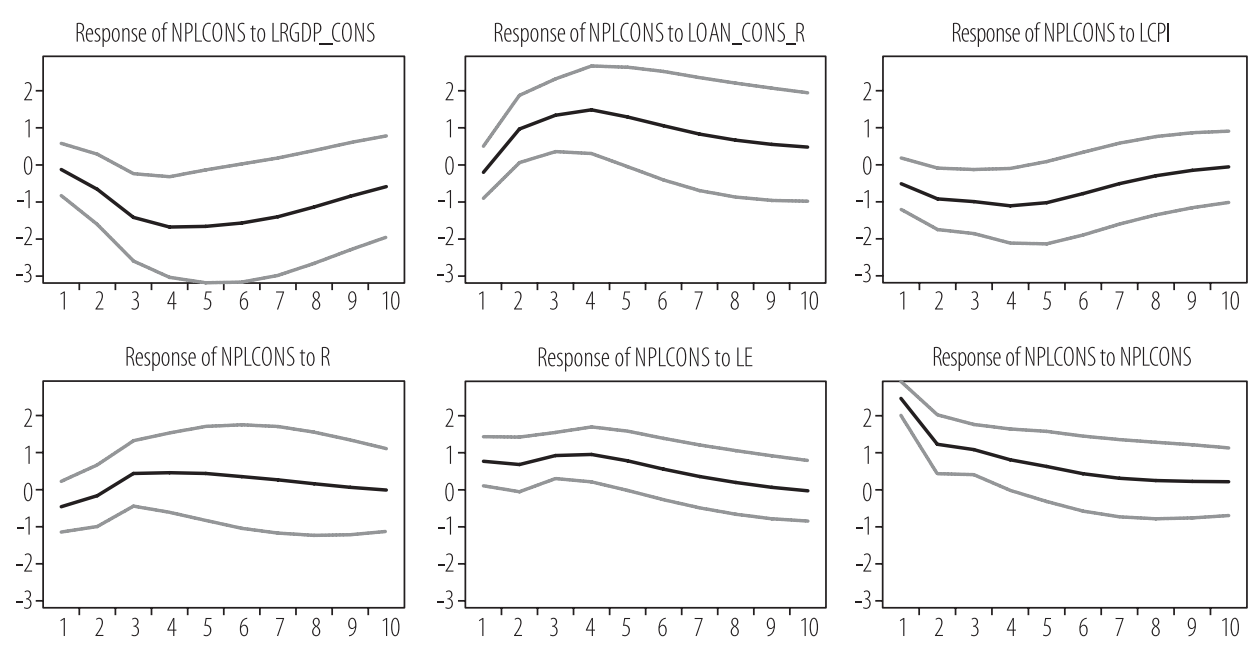


\section{Figure 10: IRF for the mining sector}
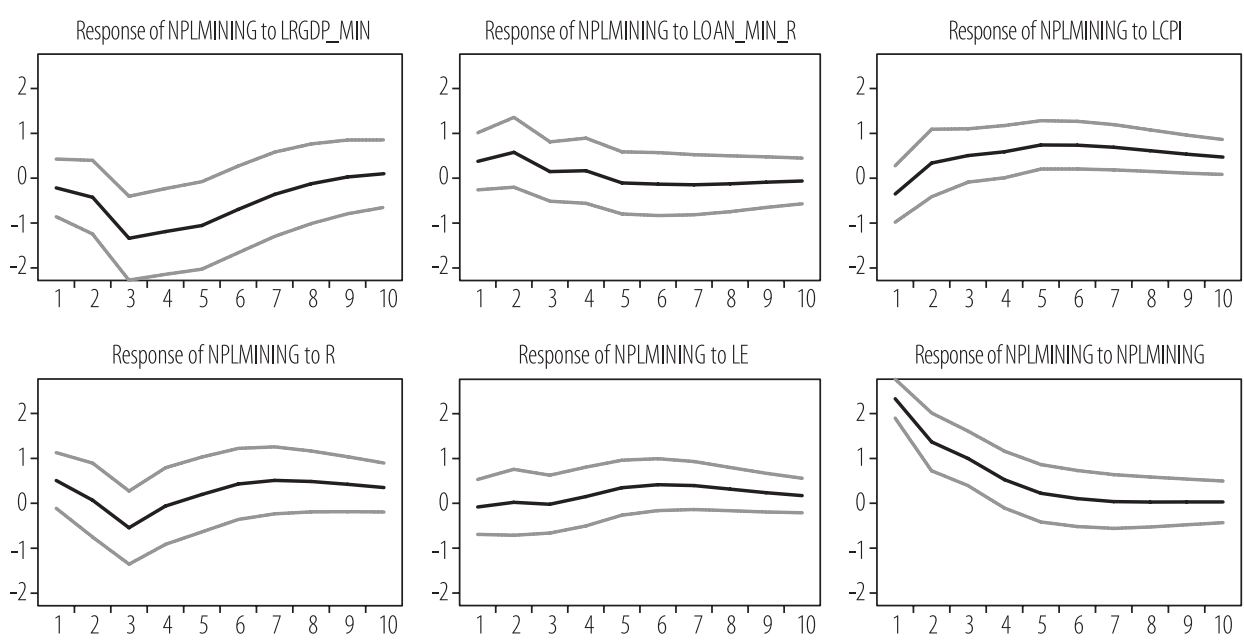

\section{Figure 11: IRF for the manufacturing sector}
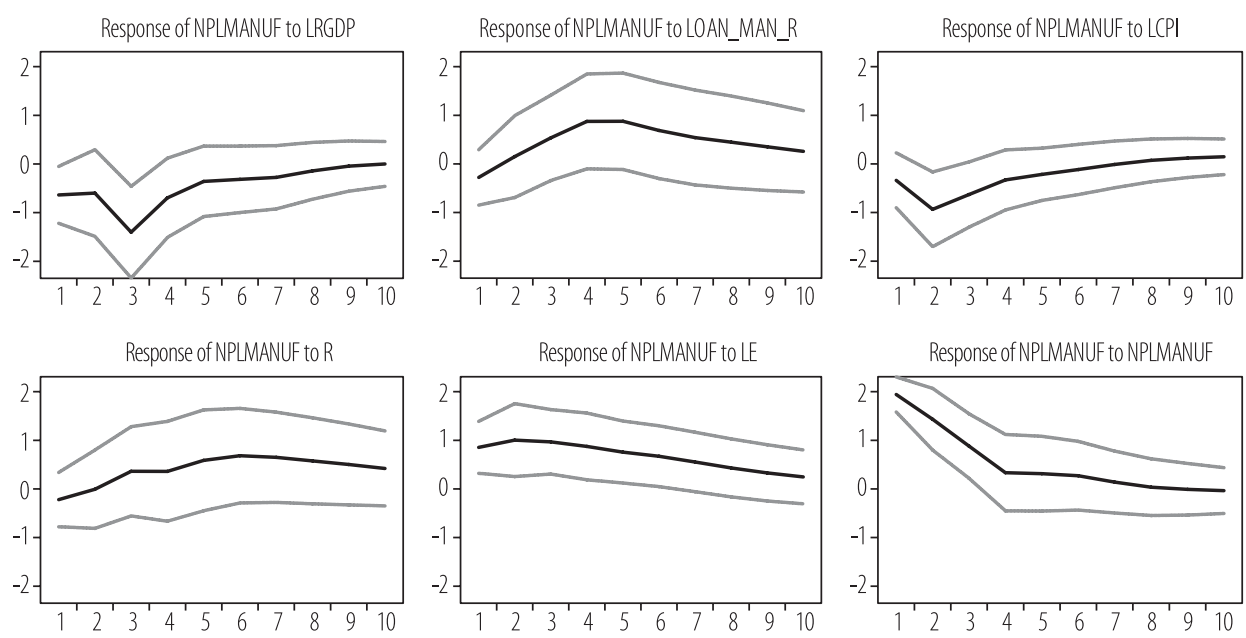


\section{Figure 12: IRF for the individual loans}
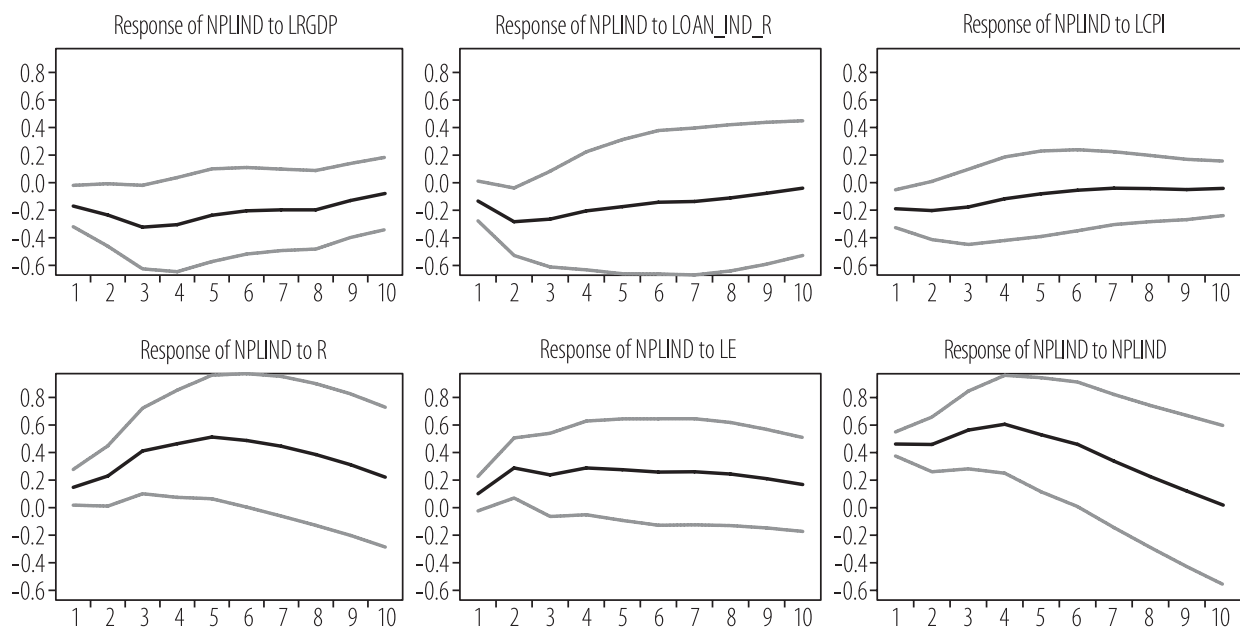

\section{Figure 13: Variance decompositions in NPLs}

Variance Decomposition of NPLTRADE using Cholesky (d.f. adjusted) Factors

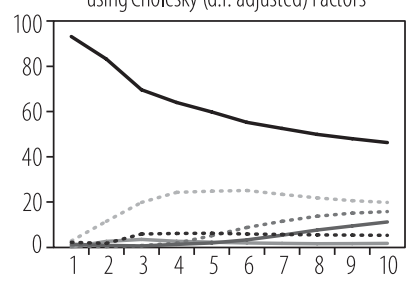

$\ldots$....LRGDP_TR - LOAN_TR_R

$\begin{array}{ll}\cdots . . . L C P \mid & -R \\ \cdots & \text { NEL }\end{array}$

Variance Decomposition of NPLCONS using Cholesky (d.f. adjusted) Factors

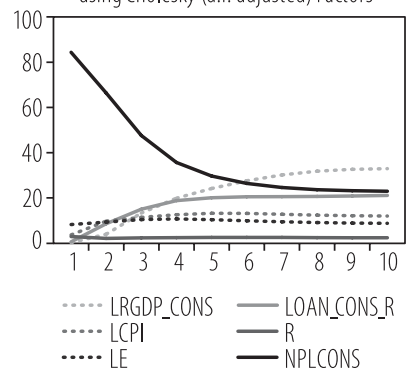

Variance Decomposition of NPLMANUF

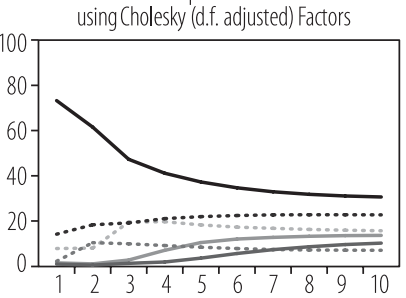

$\ldots$ LRGDP — LOAN_MAN_R

$\cdots L$... LCP

..... LE

- R

Variance Decomposition of NPLIND

using Cholesky (d.f. adjusted) Factors

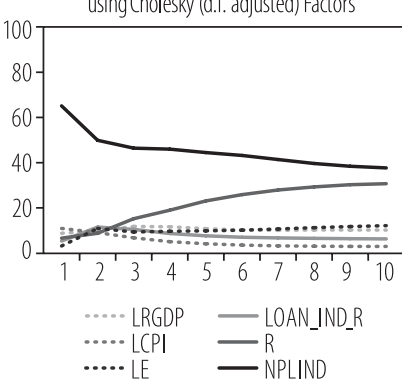

Variance Decomposition of NPLMINING

using Cholesky (d.f. adjusted) Factors



$\ldots$....RGDP_MIN LOAN_MIN_R

$\ldots L C P \mid-R$

.....LE 
Table 1: Data description

\begin{tabular}{|c|c|c|}
\hline Variables & Definition & Sources \\
\hline NPL & Ratio of NPLs to Total loans & Bank of Mongolia \\
\hline GAP & Gap between potential and actual GDP & National Statistical Office of Mongolia \\
\hline LCPI & Natural logarithm of consumer price index & National Statistical Office of Mongolia \\
\hline $\mathrm{R}$ & Interest rate of banks & Bank of Mongolia \\
\hline CBBR & Central bank bill rate & Bank of Mongolia \\
\hline LE & Natural logarithm of nominal exchange rate & Bank of Mongolia \\
\hline SIZE & The relative market share of bank in total banks & Bank of Mongolia \\
\hline ROA & Return on assets & Bank of Mongolia \\
\hline LXPI & Natural logarithm of export price index & National Statistical Office of Mongolia \\
\hline LRGDP & Natural logarithm of real GDP & National Statistical Office of Mongolia \\
\hline NPL_cons & Level of NPLs in construction section & Bank of Mongolia \\
\hline NPL_man & Level of NPLs in manufacturing section & Bank of Mongolia \\
\hline NPL_min & Level of NPLs in mining section & Bank of Mongolia \\
\hline NPL_trade & Level of NPLs in wholesale and retail trade sector & Bank of Mongolia \\
\hline NPL_ind & Level of NPLs in consumer loans & Bank of Mongolia \\
\hline LRGDP_cons & Natural logarithm of real GDP in construction sector & National Statistical Office of Mongolia \\
\hline LRGDP_man & Natural logarithm of real GDP in manufacturing sector & National Statistical Office of Mongolia \\
\hline LRGDP_min & Natural logarithm of real GDP in mining sector & National Statistical Office of Mongolia \\
\hline LRGDP_tr & Natural logarithm of real GDP in trade sector & National Statistical Office of Mongolia \\
\hline LOAN_cons_r & Ratio of construction sector's loans to total loans portfolio & Bank of Mongolia \\
\hline LOAN_man_r & Ratio of manufacturing sector's loans to total loans portfolio & Bank of Mongolia \\
\hline LOAN_min_r & Ratio of mining sector's loans to total loans portfolio & Bank of Mongolia \\
\hline LOAN_tr_r & Ratio of trade sector's loans to total loans portfolio & Bank of Mongolia \\
\hline LOAN_ind_r & Ratio of consumer loans to total loans portfolio & Bank of Mongolia \\
\hline
\end{tabular}

Table 2: VAR Lag Exclusion Wald Tests

Chi-squared test statistics for lag exclusion:

Numbers in [ ] are p-values

\begin{tabular}{cccccc}
\hline & $\begin{array}{c}\text { Trade } \\
\text { Joint }\end{array}$ & $\begin{array}{c}\text { Construction } \\
\text { Joint }\end{array}$ & $\begin{array}{c}\text { Manufacturing } \\
\text { Joint }\end{array}$ & $\begin{array}{c}\text { Mining } \\
\text { Joint }\end{array}$ & $\begin{array}{c}\text { Individual } \\
\text { Joint }\end{array}$ \\
\hline Lag 1 & 140.0393 & 199.8939 & 227.5976 & 170.0223 & 348.0728 \\
\hline Lag 2 & {$[0.0000]$} & {$[0.0000]$} & {$[0.0000]$} & {$[0.0000]$} & {$[0.0000]$} \\
\hline Lag 3 & 42.23768 & 59.44806 & 56.88243 & 53.15427 & 236.5699 \\
\hline df & {$[0.2194]$} & {$[0.0083]$} & {$[0.0148]$} & {$[0.0326]$} & {$[0.0000]$} \\
\hline
\end{tabular}

